\title{
BACKPACKERS: THE NEED FOR RECONCEPTUALISATION
}

Frederick Dayour* ${ }^{*}$ Albert N. Kimbu, Sangwon Park

University of Surrey, School of Hospitality and Tourism management, UK.

*Corresponding author: E-mail address: f.dayour@surrey.ac.uk (F. Dayour)

Tel.:+44(0)7444524164

\begin{abstract}
Indubitably, an eclectic body of academic literature exists on backpacking dating back from the start of the 1990s. However, the characterisation of backpackers in several studies points evidently to incongruities among researchers. Consequently, there is as yet no standard operational criteria for defining backpackers. Ergo, this paper seeks to highlight and critique these existing springs of misunderstanding and to rouse the need to rethink the definition of a backpacker for valid data gathering.
\end{abstract}

Keywords:

Backpackers

Definitional criteria

Flashpackers

Reconceptualisation 
Despite the wide stream of academic literature on backpackers since the 1990s, there appears to be some ambiguity and inconsistency in the characterisation of a 'backpacker'. Accordingly, the main purpose of this paper is to highlight and critique the existing sources of confusion and call for more research dedicated towards having a more precise definition of a backpacker. We argue that the inability to arrive at an acceptable standard definition of a backpacker, a term originally coined in academic literature by Pearce (1990), could have serious implications for data validity in backpacker research. Consequently, we navigate and evaluate some of the areas of contradictions in the extant literature to substantiate our argument for the need for a reconceptualisation of a backpacker in future research.

Historically, the neologism 'backpacker' takes its root from the 17th and 18th Centuries 'Grand Tours' (GT) of the moneyed upper class - sons and daughters of English Aristocrats who travelled Europe as part of their career development and educational needs. Later, attributable to increased proliterianisation and democratisation of travel - resulting from social change and spatial reorganisation - the phenomenon of the GT metamorphosed into the concepts of 'drifting', 'wandering', and 'tramping' around the 1950s (Loker-Murphy \& Pearce, 1995). The advancement of research interests in backpacker tourism since the 1990s has been ascribed, chiefly, to the social and economic advantages it brings to destinations especially, to the developing world - that can effortlessly and expediently use local resources to cater to the needs of these low-cost travellers (Scheyvens, 2002).

Arguably, the description of today's 'backpacker' would be flawed without a trace to the 'drifter' concept which arose from Cohen's (1972) typology of tourist roles (based on novelty and familiarity) on a continuum of 'organised to solo institutionalised mass tourists' to 'explorer' to 'drifter' tourists. Notably, Pearce's (1990, p. 1) defining criteria is often used as a reference point for the conceptualisation of a backpacker in current research. He operationalises backpackers as:

a group of predominantly young travellers who are more likely to stay in budget accommodation, have an emphasis on meeting other travellers, are independent and have a flexible travel schedule, stay for a longer rather than a brief holiday, and focus on informal and participatory holiday activities.

Essentially, Pearce's study is mainly concerned with the motivational drivers, primarily related to prolonging one's education: travel as an escape from irresistible life choices, and sporadic work to lengthen travel time. He also attributes the growth of the backpacker segment to a positive change in the travel industry, which saw the establishment of Youth Hostel Association (YHA) in Australia in the 1990s. His work is momentous in that the expression of the term is not merely a semantic difference, but rather, a major modification of it from a de-marketing marker to a marketing one - in the framework of the increasing economic value of this segment. Following Pearce (1990), backpacking has become a well-founded subject area around which a growing body of research is focussed, in defining and re-defining the phenomenon, often conflating different parameters in the literature. For instance, Table 1 shows a summary of several parameters comprising socio-demographics, accommodation choices, motivations, travel characteristics, belongingness to virtual communities, travel budget, and self-identification among others that have been used to operationalise backpackers, which are currently questionable. These varied parameters could not be anything more than an attestation that the debate around a more suitable operationalisation of backpackers is as yet unresolved. The diversity in the current conceptualisations raises concerns about the actual identity of backpackers, which if remains unaddressed, may imply that some studies do not actually study backpackers. 


\begin{tabular}{ll}
\hline Table 1: Summary of existing defining criteria of a 'backpacker' (1990-2017) \\
\hline Criteria
\end{tabular}

I: Socio-demographic - age

18 and 30 years

Loker, 1991

15 and 24 years

Hunter-Jones, Jeffs, \& Smith, 2008

II: Motivation for travel

Leisure oriented travels

Adam, 2015

\section{III: Travel characteristics}

Patronise budget accommodation facilities; youth hostels

Pearce, 1990; Dayour, Adongo \& Taale,

2016; Zhang, Tucker, Morrison \& Wu, 2017

Carrying of backpacks, backpacker hostels \& independent travellers

Zhang, Morrison, Tucker, \& Wu, 2017

Youth hostels \& chain

referrals/snowballing

Zhang, Tucker, Morrison \& Wu, 2017

Travel for several months to years

O’Reilly, 2006

Peregrinating for 1 year or more

Elsrud, 2001

IV: Virtual communities

Members of Facebook backpacker groups

Paris, 2012

Users of backpacker Internet sites

O’Reilly, 2006

\section{$V$ : Enclaves}

Users of backpacker enclaves/ 'metaworld'

Sorensen, 2002

\section{VI: Self-identification}

An admission of being a backpacker

Invitation to participate

Reichel, Fuchs, \& Uriely, 2007

Cohen, 2011

Uriely, Yonay, \& Simchai, 2002

\section{VII: Economic criterion}

Budget traveller

O’Reilly, 2006

Authors' construct, 2017

Pearce's (1990) definition, though overarching, assumes that a typical backpacker ought to have a number of qualities to be regarded as such but this could be a potential source of confusion and challenge to researchers who wish to adopt those proposed criteria in selecting backpackers for research. Must a backpacker meet all such criteria to be classified as such? In terms of using 'self-identification' as a definitional criterion for backpackers (e.g. HunterJones, Jeffs, \& Smith, 2008), a notable downside to it is that not every backpacker may contentedly yield to such an approach as backpacking has been historically linked with travels to psychedelic enclaves for illicit drug consumption. Thus, it may appear pejorative to some people. Extant literature has also drawn our attention to a growing class of backpackers christened 'flashpackers' who have the proclivity for upscale services including accommodation, have more income, and use a relatively substantive amount of technology to 
enhance their travel experience and sociality (Paris, 2012). This insight suggests that the use of either a budget accommodation facility (e.g. hostels) or travel budget as an operational criterion for selecting backpackers could be unrepresentative. Moreover, while some researchers constrict backpackers within a certain age brackets, others argue that backpackers can belong to any age category as this is becoming a lifestyle than a 'rite of passage' for people belonging to a Western youth class (e.g. Reichel, Fuchs, \& Uriely, 2007). What is more, there is also the claim that backpackers are becoming less distinct from mainstreamers in terms of their travel motivations and risk taking tendencies, which implies that the use of motivations as a selection criterion could be misleading now (Reichel, Fuchs, \& Uriely, 2007).

This far, the paper, demonstrates that researchers are using diverse criteria in operationalising the term 'backpacker', and there is yet to be a common acceptable operational criteria (ion) for it. Moreover, most of these operational criteria are currently fraught with limitations that could be problematic for researchers wanting to pursue studies in this niche travel segment. Therefore, we call for a more focussed research effort at redefining a backpacker following the concerns raised above to provide clear criteria(ion) with which backpackers can be correctly identified for valid data gathering. We further call for a clarification study to be funnelled on the niceties of the segment, especially, contemporary backpackers who seem to set themselves apart from traditional backpackers just as they also bracket themselves out of conventional tourist segments.

\section{References}

Adam, I. (2015). Backpackers' risk perceptions and risk reduction strategies in Ghana. Tourism Management, 49, 99-108.

Cohen, E. (1972). Toward a sociology of international tourist. Social Research, 39(1), 164189.

Cohen, S. (2011). Lifestyle travellers. Annals of Tourism Research, 38(4), 1535-1555.

Dayour, F. Adongo, A. C., \& Taale, F. (2016). Determinants of backpackers' expenditure. Tourism Management Perspectives, 17, 36-43.

Elsrud, T. (2001). Risk creation in traveling: Backpacker adventure narration, Annals of Tourism Research, 28, 597-617.

Hunter-Jones, P., Jeffs, A., \& Smith, D. (2008). Backpacking your way into crisis: An exploratory study into perceived risk and tourist behaviour amongst young people, Journal of Travel and Tourism Marketing, 23(2/4), 237-248.

Loker, L. (1991). The backpacker phenomenon II: More answers to further questions. Townsville: Department of Tourism, James Cook University.

Loker-Murphy, L., \& Pearce, P. (1995). Young budget travellers: Backpackers in Australia, Annals of Tourism Research, 22, 819-843.

O'Reilly, C. C. (2006). From drifter to gap year tourist - mainstreaming back- packer travel. Annals of Tourism Research, 33, 998-1017

Paris, C. M. (2012). Flashpackers: An emerging sub-culture? Annals of Tourism Research, 39(2), 1094-1115.

Pearce, P. L. (1990). The backpacker phenomenon: Preliminary answers to basic questions. Townsville: James Cook University of North Queensland.

Reichel, A., Fuchs, G., \& Uriely, N. (2007). Perceived risk and the non-institutionalised tourist role: The case of Israeli student ex-backpackers. Journal of Travel Research, 46(2), 217-226.

Scheyvens, R. (2002). Backpacker tourism and Third World development. Annals of Tourism Research, 29(1), 144-164.

Sorensen, A. (2003). Backpacker ethnography. Annals of Tourism Research, 30, 847-867 
Uriely, N., Yonay, Y., \& Simchai, D. (2002). Backpacking experiences: A type and form analysis. Annals of Tourism Research, 29(2), 520-538.

Zhang, J., Morrison, A. M., Tucker, H., \& Wu, B. (2017). Am I a backpacker? Factors indicating the social identity of Chinese backpackers. Journal of Travel Research, 1-15.

Zhang, J., Tucker, H., Morrison, A. M., \& Wu, B. (2017). Becoming a backpacker in China: A grounded theory approach to identity construction of backpackers. Annals of Tourism Research, 64, 114-125. 